\title{
Inheritance Rights of Children Out of Wedlock in the Perspective of Islamic Law
}

\author{
Sri Istiawati ${ }^{1}$, Yusriana $^{2}$, Deliani $^{3}$, Saniah $^{4}$ \\ 1,2,3 Universitas Amir Hamzah, Medan, Indonesia \\ ${ }^{4}$ STIE Nusa Bangsa Medan, Indonesia \\ sriistiawati1962@gmail.com,majrulsaniah@gmail.com,deliani@gmail.com
}

\begin{abstract}
The aims of study are to find out Inheritance Rights of Children Out of Wedlock in the Perspective of Islamic Law. This study use qualitative research. The result in this study shows that Pregnancy out of wedlock will have a huge psychological impact on the child. The child will be ostracized in the midst of society and there will be tremendous confusion when he grows up to marry because it may be without his biological parents, especially his father, attending.
\end{abstract}

Keywords

Inheritance; children; perspective of Islam

\section{Introduction}

The phenomenon of pregnancy outside of marriage (non-marital) in recent years has increased. Many factors are the cause, among others: because of the increasing prevalence of promiscuity, infidelity/adultery and cases of rape. The impact that arises is of course not just a violation of the normal limits of morality, but also the pregnancy that will be experienced by the woman. Likewise, victims of rape cases are not only disgraced, but also suffer a lifetime of psychological burden and the loss of several opportunities due to the disgrace of being raped. Of course, this will have an impact that must be borne by the women themselves, namely psychological trauma for rape victims and unwanted pregnancies in both cases.

In some cases, the woman prefers to abort her pregnancy rather than having to endure the feeling of shame both in front of her parents and in front of the general public. However, not a few also choose to maintain the pregnancy even though he did not expect it on the pretext that he does not want to kill an innocent fetus and does not want to increase his sin for him, the method of aborting the fetus is an inhumane act, because the effort is not based on good reasons justifiable by law.

Pregnancy out of wedlock will give birth to a legal phenomenon, so what about the status of the child? Because we know he only had a mother and was born without a father. Whereas a legitimate child is a child born as a result of a legal marriage (see Article 42 of the Marriage Law No. 1 of 1974). Then, when he grows up, if the child is a girl, who has the right to be his guardian when he gets married? What are the inheritance rights of children out of wedlock? These questions need answers at a later date. 
Konfrontasi Journal: Culture, Economy and Social Changes, 8 (3) September 2021, 186-196

ISSN: 1410-881X (Print), 2716-2095 (Online)

Sri Istiawati, Yusriana, Deliani, Saniah: Inheritance Rights of Children Out of Wedlock in the Perspective of Islamic Law

DOI: https://doi.org/10.33258/konfrontasi2.v8i3.156

http://www.konfrontasi.net/index.php/konfrontasi2

\section{Review of Literature}

\subsection{Family}

Family is the smallest unit of public consisting of head of family and some people who are gathered and also people who always accept the shortcomings and advantages of those around them, good or bad family members, still cannot change the existing nature, the outline of the good is directed and the bad is corrected without having to judge.

Family life is bound by the existence of relationships between family members. Relationships in the family can be viewed from the dimensions of blood relations and social relations. The family in the dimension of blood relations is a unit that is bound by the relationship or blood relations between one another. While in the dimensions of social relations, the family is a unit that is bound by the existence of interconnected or interacting and influencing each other with each other even though among them do not have blood relations. (Hendra, Y and Priadi, R. 2019)

The family is the main pillar of life, especially for young generation. The family is the first educator and guard leader to realize human resources. For that the total support of the family is able to give birth as if a miracle in their life. Such is the urgency of the function of the family as the smallest organization in the structure of society that contributes to the character and the mental state. (Thariq, M. 2018)

According to Salvicion and Celis (1998) in the family there are two or more than two individuals who are joined because of a relationship blood, marital relations or adoption, in his life in one household, interact with each other and in their respective roles and create and maintain a culture. Based on Law 52 of 2009 concerning Population Development and Family Development, Chapter I article 1 paragraph 6 understanding

The family is the smallest unit in society consisting of husband and wife; or husband, wife and children; or father and child (widower), or mother and child (widow).

Basically, there are eight main tasks for the family as follows:

- Physical maintenance of the family and its members.

- Maintenance of existing resources in the family.

- The division of tasks for each member according to their respective positions.

- Socialization between family members.

- Setting the number of family members.

- Maintenance of order in family members.

- Placement of family members in the wider community.

- Generating encouragement and enthusiasm of its members.

There are two types of family based on how decisions are made, namely based on location and based on patterns of authority.

\section{a. By location}

- Utrolocal customs, namely the custom that gives freedom to a husband and wife to choose a place to live, either in the vicinity of the residence of the husband's relatives or around the residence of the wife's relatives;

- Virilocal customs, namely the custom that stipulates that a husband and wife are required to live in the vicinity of the residence of the husband's relatives;

- Uxurilocal customs, namely the custom that stipulates that a husband and wife must live in the vicinity of the residence of the wife's relatives; 
- Bilocal custom, namely the custom that determines that a husband and wife can live around the center of the residence of the husband's relatives at a certain time, and around the center of residence of the wife's relatives at a certain time (alternately);

- Neolocal customs, namely the custom that determines that a husband and wife can occupy a new place, in the sense of the word not being in groups with the husband's or wife's relatives;

- Avulkulocal customs, namely the custom that requires a husband and wife to live in the vicinity of the residence of the mother's brother (avunculus) from the husband's side;

- Christmas custom, namely the custom that dictates that the husband and wife each live separately, and each of them also lives in the vicinity of his own kinship center.

\section{b. Based on the pattern of authority}

- Patriarchal, i.e. the authority in the family belongs to the male (eldest male, usually the father)

- Matriarchal, i.e. authority in the family belongs to women (eldest woman, usually mother)

- Equalitariani.e. husband and wife share authority equally.

\subsection{Child}

Understanding children according to civil law is built from several civil aspects that exist in children as legal subjects that are not yet perfect. These legal aspects are:

- Minor status (age limit) as a legal subject. Children's rights in civil law.

Article 330 of the Civil Code provides the understanding that children are minors who have not reached the age of 21 (twenty one) years and have not previously been married. This definition is the same as that stated by Law no. 4 of 1979 concerning Child Welfare in article 1 paragraph (2) states that a child is someone who has not reached the age of 21 (twenty one) years and has never been married". This understanding of children is placed in the same meaning as those who are not yet mature and someone who has not reached the age limit of legal legitimacy as a legal subject or like a normal legal subject determined by civil law.

In the provisions of civil law, children have a very broad position and have a very important role, especially in terms of protection of children's civil rights. For example, in the matter of the distribution of inheritance, so that even a child who is in the womb of a woman is considered to have been born if the interests of the child so desire as intended by Article 2 of the Civil Code. In addition, the child has the right to care and protection both while still in his mother's womb and after birth, so that if the interests of the child so desire, the child in the womb of a woman is considered to have been born. Meanwhile, a child who dies at birth is considered to have never existed.

Because everyone regardless of age is a legal subject, everyone has the "right authority" because he is a legal subject. However, not everyone is capable of carrying out legal actions. In general, people who are called adults (meerderjarig) can carry out legal actions legally, unless the law does not provide so. Article 2 paragraph (1) of the Civil Code stipulates that "a child in a woman's womb is considered to have been born, if the interests of the child demand it". Article 2 paragraph (1) of the Civil Code above contains the intent that a person's personality begins at birth. On the other hand, a child who has not been born yet has no personality. Therefore, every child born alive, has a personality so that he has legal authority (rechtsbevoegdheid). No matter how short his life was, he had enjoyed his civil rights and after he died these rights were transferred to someone else. The rights obtained at the time he was born, provided that certain conditions may apply retroactively to children who have not been born for the benefit of that child. The conditions for the implementation of the article 
above include, among others; first, that the child has been born; second, that he was born alive; third, that their interests bring with them the demands of their rights.

\subsection{The Definition of Children According To Marriage Law No.1 of 1974 and the Compilation of Islamic Law}

Law No.1 of 1974 does not directly regulate the benchmark for when someone is classified as a child. However, Article 6 paragraph (2) contains provisions on the terms of marriage for people who have not reached the age of 21 years, they must obtain permission from their parents. Article 7 paragraph (1) of this law also stipulates that the minimum age for marriage for men is 19 (nineteen) years and for women 16 (sixteen) years.

Then in Article 47 paragraph (1) it is stated that children who have not reached the age of 18 (eighteen) years or have never been married are under the authority of their parents as long as their parental authority is not revoked. Article 50 paragraph (1) also states that children who have not reached the age of 18 (eighteen) years or have never been married, who are not under the authority of their parents, are under the authority of a guardian. From the articles above, it can be concluded that children in Law no. 1 of 1974 are those who are not yet mature and have reached maturity, namely 16 (sixteen) years for women and 19 (nineteen) years for men.

The Compilation of Islamic Law determines maturity based on the signs of physical changes, both for men and women. So, what is used to determine the age limit of maturity for children is to look at the problem first. In general terms, the age limit for maturity is 18 years, based on the legal principle of lex specialis derogat legi generali (specific laws override general laws). The exception in the case of marriage is that the minimum age for marriage for men is 19 years and for women it is 16 years. Children who have not reached the age of 18 years are under the control of their parents as long as their authority is not revoked, it is the parents who represent the child in legal actions inside and outside the court building.

\subsection{Understanding Child According to Criminal Law}

Understanding children in criminal law is prioritized on understanding children's rights that must be protected. Because by nature, children have weak substance and in the legal system are seen as legal subjects that are grafted from the form of responsibility as befits a normal legal subject. In the Criminal Code, it does not explicitly stipulate the limits on whether a person is said to be an adult or still in the category of a child. However, we can see in Articles 45, 46, and 47 concerning the regulation that a person who commits a crime and has not reached the age of 16 (sixteen) years receives a reduced threat of punishment compared to adults. Thus it can be said that according to the Criminal Code, the age limit of a child is said to be an adult if he has reached the age of 15 years or 16 years.

Understanding children in the aspect of criminal law raises positive legal aspects to the process of normalizing children from deviant behavior to form personalities and responsibilities which ultimately make the child entitled to proper welfare and a good future. Therefore, if the child is involved in a criminal case, the judge may order that the guilty person be returned to his parents, guardian or guardian without being subject to a penalty, or order that it is handed over to the government without being subject to a penalty. 


\subsection{Definition of Children According to Law No. 3 of 1997 Concerning Court of Child.}

In Law no. 3 of 1997 states that a child is "a person who in the case of a naughty child has reached the age of 8 (eight) years but has not yet reached the age of 18 (eighteen) and has never been married." In this sense, it provides a special classification according to the characteristics adopted by the law itself, namely about naughty children. Those who are referred to as children are based on the age category of 8 (eight) years but have not yet reached the age of 18 (eighteen) years and have never been married. This understanding also provides an interpretation that every person under the age of 18 (eighteen) years who has been married is no longer categorized as a child but is an adult.

In Article 1 paragraph 2 of Law No. 3 of 1997 it is stated that a naughty child is: a child who commits a crime; or a child who commits an act that is declared forbidden for a child, either according to the laws and regulations or according to other legal regulations that live and apply in the community concerned.

\subsection{Definition of Children According to Child Protection Law UU No. 23 Year 2002}

In law no. 23 of 2002 concerning Child Protection Article 1 number (1) states "A child is someone who is not yet 18 (eighteen years old), including children who are still in the womb". The definition of a child in this law does not mention that the child's maturity is reached earlier as is stated in the Convention on the Rights of the Child (KHA) or what is stated in Law No., is said to have grown up.

The protection of children as stated in this law is aimed at ensuring the fulfillment of children's rights so that they can live, grow, develop and participate optimally in accordance with human dignity and protection, and receive protection from violence and discrimination, for the realization of quality Indonesian children., noble, and prosperous. It is specifically explained that special protection is given to children in emergency situations, children who are in conflict with the law (children conflict with low), other conditions mentioned in the emergency category for children who need special protection.

\subsection{Understanding Children According to Some Conventions and Ratifications}

Law No. 39 of 1999 concerning Human Rights also explicitly recognizes the existence of children. In this law, a child is every human being who is under 18 (eighteen) years of age and unmarried, including a child who is still in the womb if this is in his interest. Furthermore, Article 52 paragraph 1 stipulates that the protection of children must be carried out by parents, families, communities and the state. Meanwhile, Article 58 paragraph 1 provides guarantees for every child to get legal protection from all forms of physical or mental violence, neglect, bad treatment, and sexual harassment while in the care of their parents or guardians, or other parties who are responsible for child care.

The United Nations General Assembly on November 20, 1990 in New York held the Convention on the Rights of the Childs (CRC), among its results stating that; Child is any person under the age of 18 years, except under the law applicable to the child, maturity has been previously obtained.

The Indonesian nation has ratified the international instrument of the Convention on the Rights of the Child (KHA) since 1990 with Presidential Decree no. 36 of 1990. According to article 1 of the Convention on the Rights of the Child, a child is defined as "Every person under the age of 18 (eighteen) years, unless based on the law applicable to children it is determined that the child's age is reached earlier".

The definition of children according to Law Number 1 of 2000 concerning Ratification of the ILO Convention Number 182 concerning the Prohibition and Immediate Action for the 
Elimination of the Worst Forms of Child Labor. Article 1 of Law No. 1 of 2000 stipulates that a child means: "all persons under 18 years of age" (in accordance with Article 2 of ILO Convention No. 182).

\subsection{Inheritance}

Legacyis a legacy left by the heir to the heirs. Inheritance in the Indonesian sense is mostly not the same as inheritance in Islam.

Inheritance in Arabic \& Islamic culture has a broader meaning. Example:

Faraidh science which is the most basic in the division of INSIGHTS between obligatory and non-obligatory. For example: Compulsory Prayer (Fardhu), zakat, Hajj. Application example Inheritance comes from Arabic Al-miirats, in Arabic is the masdar (infinitive) form of the word waritsa-yaritsu-irtsan-miiraatsan. Its meaning according to language is 'the transfer of something from one person to another'. Or from one race to another. Heirs are people who are entitled to receive the inheritance (inherit) of the person who died, either because of a relationship family, wedding, as well as for liberating slaves (wala').

Inheritance property which in fara'id terms is called tirkah (relic) is something left by the person who died, either in the form of money or other material justified by the deceased. Islamic law to be passed on to their heirs.

\subsection{Inheritance and Legal Basis of Inheritance}

An heir is a person who dies, both male and female, who leaves a number of property and rights acquired during his life, either with a will or without a will. As for the basis for the right to inherit or the basis for obtaining a share of the inheritance according toAl-Qur'anthat is:

a. Because of blood relations, this is clearly specified in the QS. An-Nisa: 7, 11, 12, 33, and 176.

b. Marital relationship.

c. Brotherly relations, because the religion determined by the Qur'an is not more than a third of the inheritance of the heir (Surah Al-Ahzab: 6).

d. Relatives because of fellow hijrah at the beginning of the development of Islam, even though there is no blood relationship (Surah Al-Anfal: 75).[4]

Problems with inheritance include:

\subsection{Pregnancy}

Pregnancy is a state when a woman brings embryo or fetusin his body. There can be many things in pregnancy gestation (for example, in the case of twin, or triplets/triplets).

Human pregnancy occurs for 40 weeks between menstruation last and birth (38 weeks from conception). The medical term for pregnant women is gravida, while humans in it are called embryo (early weeks) and then fetusor fetus (until birth). A woman who is pregnant for the first time is called a primigravida or gravida 1. A woman who has never been pregnant is known as a gravida 0 .

In many societies the medical and legal definitions of human pregnancy are divided into three periods quarterly, as a means of facilitating different stages of fetal development. The first quarter carries the highest riskmis carriage (natural death of the embryo or fetus), while in the 2nd trimester fetal development can be monitored and diagnosed. The 3rd quarter marks the start of 'viability', which means the fetus can remain alive in the event of a natural early birth or forced birth. 


\section{Discussion}

Pregnancy out of wedlock will give birth to a legal phenomenon, so what about the status of the child? Because we know he only had a mother and was born without a father. Whereas a legitimate child is a child born as a result of a legal marriage (see Article 42 of the Marriage Law No. 1 of 1974). Then, when he grows up, if the child is a girl, who has the right to be his guardian when he gets married? What are the inheritance rights of children out of wedlock? These questions need answers at a later date.

Answering the questions above, the author will describe based on the classification of the origins of the causes of the emergence of children out of wedlock based on events/events. Because each event has a different law. This is based on As-Sunnah Magazine Edition 10/Tahun XIX/1437H/2016M published by the Lajnah Istiqomah Surakarta Foundation, adapted by the author.

1. If a woman commits adultery and then becomes pregnant

The condition of a woman who commits adultery can be categorized as a result of the influence of promiscuity so that she commits acts that violate moral boundaries such as having non-marital sex (out of wedlock). Based on the consensus of scholars, a child who is born based on the result of a non-marital sexual relationship, then the status of the child will be assigned to the mother's child and not to the biological father.

His relationship with his biological father was severed, including legally his inheritance. He only has the right to inherit from his mother and vice versa, his mother has the right to inherit it.

Then the one who has the right to become a marriage guardian when he gets married later is the judge's guardian, because he cannot be assigned to his biological father.

2. If there is an oath of li'an between husband and wife

The definition of a lin oath is an oath made by a husband and wife in the name of Allah because the husband accuses his wife of adultery or does not recognize the child conceived or born by his wife as his biological child where the husband has no witnesses to the accusation, while the wife rejects the accusation.

Usually this happens because the husband is prejudiced or alleges that his wife during his marriage with him had an affair and committed adultery with another man, resulting in pregnancy. Or it could be because the husband really knows that his wife has had an affair and commits adultery with another man but he has no evidence or witnesses, while the wife denies the allegation that her pregnancy was caused by the adultery.

So in this case, the husband and wife must carry out the li an oath, in which the husband takes an oath four times to confirm his accusation and the wife takes an oath four times to deny the husband's accusation, followed by both taking a fifth oath which states that if he lies then the curse of Allah be with him. Furthermore, husband and wife must separate forever and may not reconcile or remarry.

The status of a child born in this condition is assigned to his mother because the husband takes the li an oath and does not recognize the child as his son. So that inheritance rights only arise between the mother and the child.

Regarding the guardian of the daughter's marriage, it will be the guardian of the judge.

3. If the wife has sexual relations with other men while the marriage is still taking place

Is a condition where the wife has sexual relations with other men, whether her husband knows or does not know that it causes her to become pregnant.

Based on the authentic hadith narrated by Imam al-Bukhari, no. 6749 and Muslim, 4/171 from Aisyah Radhiyallahu anhuma in a long hadith it is stated that: "The child is the 
right (male) who has a bed and for those who commit adultery do not have any rights (over the child).

This incident is different from the li'an oath because in this case the husband may not know it, or the husband may know but he is reluctant to take the li an oath. So in this case, the status of the child who is born will be assigned to the legal husband, not to the man who is having an affair with his wife.

So that the right to be the guardian of the daughter's marriage later is her father (husband of her mother). Then because she is still assigned to her father, the daughter has the right to inherit from her mother's father and vice versa.

4. If a woman has sexual relations outside of marriage, then she becomes pregnant and is married to the man who impregnated her.

Is a condition where an unmarried woman has sexual relations with men until she becomes pregnant. This case is almost the same as point number 1 , the difference is that in this case the man who has sexual relations with her wants to be responsible for marrying her.

In this case, the status of the child who will be born is assigned to the mother because in this case it cannot be included in the general hadith such as number 3, because the husband and wife married after the wife was pregnant first, not before pregnancy. Even so, the man can still be said to be the biological father of the child, but cannot be attributed to the biological father.

Therefore, the one who has the right to become a marriage guardian when the girl is married is the judge's guardian, because her status is only as the mother's child even though her biological father marries her mother. It's just that the difference with criterion number 1 is that the daughter is legally written, the birth certificate will include the names of the father and mother. This is based on the Compilation of Islamic Law which states explicitly as follows:

Article 53 Compilation of Islamic Law

- A pregnant woman out of wedlock, can be married to a man who impregnates her.

- The marriage with a pregnant woman referred to in paragraph (1) can be carried out without waiting for the birth of her child.

- With the marriage taking place when the woman is pregnant, there is no need for remarriage after the child is born

So that based on article 53 of the Compilation of Islamic Law, what must be understood is the validity of pregnant marriages, but it has no impact on children caused by marriage due to pregnancy. Children resulting from pregnant marriages do not necessarily include the lineage of their parents. Therefore, this is where the importance of lineage in Islam can only be obtained through marriage.

Regarding inheritance rights, because they are only assigned to their mothers, the daughter can only inherit from each other with her mother.

5. If a woman has non-marital sexual relations and then becomes pregnant and then marries another man who did not impregnate her

There is a difference of opinion among scholars in this regard. The two opinions are as follows:

- The first opinion says it is permissible and lawful to be married. The madhhabs of Imam Syafi'i rahimahullah and Imam Abu Hanifah rahimahullah reasoned that the woman was pregnant because of non-marriage sexual relations, not from marriage, even though we already know that according to syara, we do not consider children born as a result of nonmarital sexual relations at all. times described above. Therefore it is lawful for another man to marry her and have sexual intercourse with her without having to wait for the 
woman to give birth to her child. However, Imam Abu Hanifah requires that he should not have intercourse until the woman gives birth.

- The second opinion says it is forbidden to marry until the woman gives birth. This is the madhhab of Imam Ahmad t and Imam Malik t. And this second school is stronger than the first and closer to the truth.

The status of the child who is born will be assigned to his mother only. not to a man who commits adultery and impregnates his mother, nor to a man who marries his mother after her mother gives birth.

So that the right to be a guardian of marriage when the daughter is married is the guardian of the judge. Then the right of inheritance only arises between the child and the mother.

6. If the child is born from a fasid or vanity marriage contract,

What is meant by a fasid or vanity marriage contract is a marriage contract that is prohibited by the Shari'a or one of the pillars of marriage is not fulfilled, causing the marriage contract to be invalid, for example: marrying a mahram, breast milk sibling, father's wife or children or in-laws or with a stepdaughter whose mother is already married. intercourse, mutàh marriage, marriage with more than four women, marriage without a guardian, and so on.

In this condition, it is categorized into:

1. If both, husband and wife do not know the fasid / vanity of their marriage, then the child is still assigned to the husband so that the husband has the right to be his marriage guardian and inheritance rights arise from him.

2. If both husband and wife know the fasid / vanity of their marriage, then the child is only the mother's child so that the right to become a guardian when the child is married is the guardian of the judge and inheritance rights only arise between the mother and child.

3. If only the husband knows the fasid / vanity of his marriage, then the child cannot be assigned to him so that the right to be the guardian of the child's marriage is the guardian of the judge and inheritance rights only arise between the mother and child.

4. If only the wife knows the fasid / vanity of her marriage, then the child is still assigned to her husband so that the husband has the right to be the guardian of the child's marriage and inheritance rights arise from him.

Furthermore, if the biological father of an illegitimate child who previously did not want to be responsible, later on he wants to legally recognize the child and wants his name listed on the child's birth certificate, then whether he can submit an application to the religious court so that his confession can be considered legally valid. law?

In this condition, the biological father of a child out of wedlock cannot submit an application to the religious court, because the child born is therefore a child of non-marital sexual relations, so he is only assigned to his mother. Likewise, legally, the child is the mother's child, so that the child's birth certificate can only include the name of the mother, even though the biological father admits it later. Even if the biological father still tries to apply to the religious court, it will likely be rejected by the religious court.

However, based on the fatwa of the Indonesian Ulema Council Number 11 of 2012 which states that "The government has the authority to impose ta'zir punishment on adulterers who result in the birth of children by requiring them to: a. To meet the needs of the child's life, b. Giving property after he died through a mandatory will.

So even though legally, the biological father cannot get legal recognition that he is the father of the child, he can still provide for the child and provide inheritance through a mandatory will. 
In contrast to the case of children born outside of a legal marriage, in this sense the child is the result of an unregistered marriage / under the hands of a woman and a man who are both not bound by a legal marriage with another woman / man. Biological fathers can apply for the origin of the child to a religious court to obtain a determination to validate the origin of the child. Which may result in legal consequences based on the determination, such as kinship relations, guardianship and inheritance. So that the child's birth certificate can later include the names of the father and mother

\section{Conclusion}

Pregnancy out of wedlock will have a huge psychological impact on the child. The child will be ostracized in the midst of society and there will be tremendous confusion when he grows up to marry because it may be without his biological parents, especially his father, attending.

\section{References}

Ali. M. (2009). Konseling Pernikahan: Perspektif Agama-Agama. Semarang: Walisongo Press.

Anastasia. H. (2001). Dampak Psikologis Perempuan Hamil Di luar Nikah. Skripsi. Semarang. Fakultas Psikologi Universitas Katolik Soegijapranata Semarang (diterbitkan).

Atkinson, R. et al. (2010). Pengantar Psikologi jilid 2. (diterjemahkan oleh Dr. Wijaya Kusuma). Jakarta: Interkasara Publisher.

Bachtiar, A. (2004). Menikahlah Maka Engkau Akan Bahagia. Yogyakarta : Sarjana

Bloomfield, M.D. (2003). Healing Anxiety Naturally. Jurnal of consulting and Clinical Psychology www.google.com. Akses 4 Mei 2011.

Cecep. H. Heri. H. Solihati. (2008). Faktor-faktor yang Berhubungan dengan Kehamilan Pranikah di Kalangan Pelajar di Desa Setianagara Kecamatan Cilimus. Kuningan. Sekolah Tinggi Ilmu Kesehatan Kuningan.

Conley, T. (2003). Breaking Free From The Anxiety Trap. Wallsent self Help Group. www.wshg.org.uk. Daradjat, Z. (2001). Kesehatan Mental. Jakarta: Gunung Agung.

Fakih, P. (2011). Profil Kecemasan dan Stres pada Pelaku Sholat Tahajjud. Skripsi. (tidak diterbitkan). Surakarta: Fakultas Psikologi Universitas Muhammadiyah Surakarta .

Gullota, T.P. (1993). Adolescent Sexuality. USA: Sage Publication Inc.

Harnawatiaj. (2008). Perubahan anatomi dan fisiologi wanita hamil. http://harnawatiaj.wordpress.com/2008/perubahan-anatomi-dan-fisiologiwanita-hamil/. Akses 4 Mei 2011.

Hendra, Y and Priadi, R. (2019). Family Communication Model in Forming Pious Children. Budapest International Research and Critics Institute-Journal (BIRCI-Journal). P. 2838.

Kartono, K. (1992). Psikologi Wanita: Mengenal Gadis Remaja \& Wanita Dewasa. Bandung: Mandar Maju.

Khisbiyah. Y. (1996). Kehamilan tak Dikehendaki di Kalangan Remaja. Yogyakarta: Pusat Penelitian Kependudukan UGM.

Lazarus, R.S. (2008). Patterns of Adjusment. LTD: Internasional Student Edition. Lestari. 2007. Perilaku Pacaran Remaja di tinjau dari Intensitas Mengakses Situs Porno dan 
Komunikasi Seksualitas Dengan Orang Tua. Laporan Dosen Muda (tidak diterbitkan). Surakarta: Fakultas Psikologi Universitas Muhammadiyah Surakarta.

Moeloeng, L.J. (2002). Metodologi Penelitian Kualitatif. Bandung: PT Remaja Rasdakarya. Monks, F \& Knoers, A.M.P. \& Haditono. 1991. Psikologi Perkembangan Pengantar Dalam Berbagai Bagiannya. Yogyakarta: Gadjah Mada University Press.

Nevid, et al. (2003). Psikologi Abnormal (jilid 1). (diterjemahkan oleh Tim Fakultas Psikologi UI). Jakarta: Erlangga. Notoatmodjo, S. 2003. Pendidikan dan Perilaku Kesehatan. Jakarta: Rineka Cipta.

Thariq, M. (2018). Interpersonal Communication Role For Selfconcept Of Children And Families. Budapest International Research and Critics Institute-Journal (BIRCIJournal). P. 182-19.

Wijaya, A. (2006). Seks Bebas. www.drawclinic.com. Akses 5 Mei 2011.

Yayasan Penerus Nilai Luhur Perjuangan 1945. (1997). Penyalahgunaan Ectacy dan Miras Serta bahaya HIV/AIDS Di Kalangan generasi Muda. Jakarta.

Yuwono, S. (2002). Kesehatan Reproduksi dan Kebugarannya, Solusi Masalah Perilaku Seksual Pranikah Remaja. Kognisi. Vol. 5, No.1, 12-2 